\title{
PROSES MANUSIA DIHADIRKAN DAN AKHIRNYA LENYAP DALAM
} KETERBATASAN BAHASA

\author{
Ruzqiyah Ulfa \\ Program Doktoral Ilmu Komunikasi-Universitas Sahid Jakarta \\ ruzqiyahulfa@gmail.com
}

\section{Spesifikasi Buku}

Judul

: Order of Thing: Arkeologi Ilmu-Ilmu Kemanusiaan

Pengarang

: Michel Foucault

Terbit pertama

: 1966

Penerjemah

: B. Priyambodo danPradana Boy

Penerbit

: PT. Pustaka Pelajar

Tahun terbit

: Februari 2007

Cetakan

$: 1$

Tebalbuku

: lxvii $+452 \mathrm{Hal}$

Harga Buku

: Rp. 75.500,-

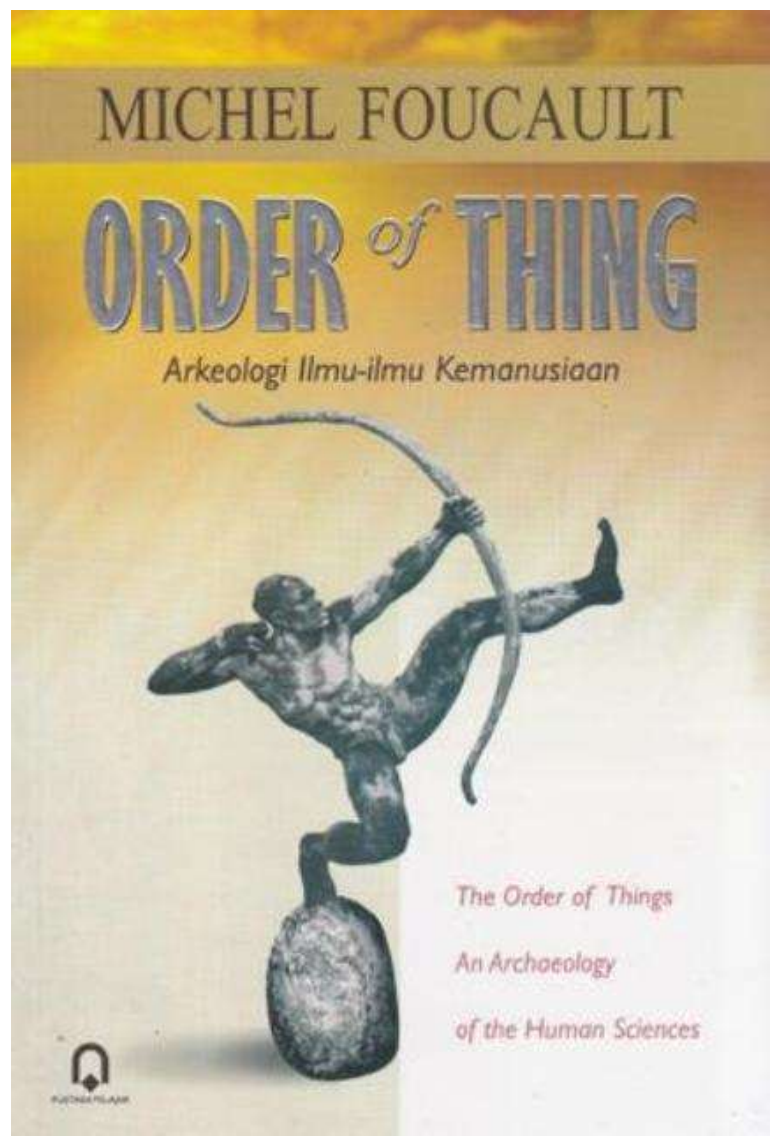




\section{Bahasa, Kekuasaan, dan Keterbatasan Ilmu Pengetahuan}

Foucault membuka buku ini dengan sebuah pengantar yang langsung menarik perhatian, yaitu tentang konsep heterotopia (hal. lvi). Istilah heterotopia adalah sebuah neologisme yang dipandang sangat mengerikan oleh Foucault, karena ia "secara diam-diam menghancurkan bahasa, karena mereka memungkinkannya untuk memberikan nama pada ini dan itu, karena mereka menghancurkan dan mengacaukan nama-nama yang umum, karena mereka menhancurkan 'sintaks' lebih lanjut" (hal. 1vi). Apakah heterotopia ini? Heterotopia merupakan sebuah tempat imajiner, suatu tempat fiksi, yang memungkinkan bahasa dibangun tanpa relasi dengan dunia nyata, tetapi pada suatu khayalan. Ini adalah sebuah dunia impian yang bagi Foucault menghancurkan bahasa. Apakah heterotopia benar-benar menghancurkan bahasa? Jika kita lihat dari perspektif positivistik, mungkin memang seperti ini. Tetapi jika kita melihat dari kacamata interpretivisme, bahwa realitas adalah bersifat subjektif, heterotopia sah-sah saja. Tetapi sepertinya memang benar kalau heterotopia menghancurkan bahasa. Tapi imajinasi sebenarnya berangkat dari dunia nyata. Hal ini dapat dilarikan pada perdebatan antara empiris dan rasionalis, seperti “adakah Burung Garuda?”. Burung ini tidak ada, tetapi ia adalah burung yang ada, hanya dibesar-besarkan. Artinya, khayalan selalu berhubungan dengan dunia nyata. Foucault berarti orang yang tidak menginginkan surealisme sebagai bagian dari bahasa dan kekayaan linguistik manusia. Menariknya, wacana heterotopia ini hanya ditemukan di bagian Pendahuluan, tetapi sama sekali tidak dibahas di bagian isi dari buku The Order of Things.

\section{Tingkat-Tingkat Bahasa}

Dalam bab awal, Foucault membuat pengantar atas apa yang akan ia paparkan secara mendalam di bukunya. Ia menjelaskan secara teknis mengenai sistem tanda di masa Stoik. Pada masa ini, elemen tanda bersifat ternari, yaitu terdiri dari tiga elemen: sistem penandaan, yang ditandai, dan konjunktur (hal. 47). Adanya sistem ternari ini memungkinkan adanya tanda yang unik dan mutlak, sederhana, material, mentah, primitif, dan memberikan stigma pada benda-benda.

Pada abad ke-17, sistem ini berubah menjadi sistem biner yang berisi penanda dan pertanda. Hal ini berakibat pada pengalaman bahasa yang lebih kaya. Lapisan purba dari sistem ternari menjadi sebuah lapisan dalaman, yang ditimpa dan menimpa lapisan purba. Lapisan purba ditimpa oleh lapisan atas yang berupa komentar yang menanggapi tanda-tanda yang telah mapan dalam lapisan purba untuk menjalankan sebuah tujuan baru. sementara itu, lapisan purba menimpa lapisan bawah yang tidak lain adalah teks. Akibatnya, teks tidak lagi dimaknai secara harfiah langsung, tetapi kata-kata tertentu, dapat tidak menggambarkan sesuatu yang sebenarnya. Bahasa kemudian menjadi tiga tingkat: tingkat komentar, tingkat purba, dan tingkat teks.

\section{Relasi Manusia dan Alam di Masa Klasik}

Foucault kemudian menjabarkan tentang bagaimana relasi manusia dengan alam pada masa klasik. Pada masa ini, manusia melupakan "bahwa manusia, kehidupan, dan alam tak satupun dari mereka menjadi domain yang menghadirkan diri mereka sendiri dengan keingintahuan pengetahuan secara spontan dan secara pasif' (hal. 82). Pada era ini, manusia sibuk dengan dunia luar dengan 
membentuk kata-kata baru untuk objekobjek baru. Penggunaan kata lama untuk hal baru terjadi secara tidak sengaja, misalnya dengan salah memahami kata dalam bahasa asing dan diambil untuk menjadi bagian dari bahasa asli. Contohnya, di Indonesia, orang Indonesia menyebut "canon" sebagai "meriam" bukan karena orang Portugis menyebut "canon" adalah "meriam", tetapi karena orang Portugis menyebut nama Bunda "Mariam" (Maryam, Maria) ketika akan menembakkan canon, sehingga disalah artikan bahwa meriam adalah nama senjata tersebut.

\section{Kekuasaan Mata atas Sejarah Alam}

Dalam bab ini, "mode wujud" yang terus menerus disebut Foucault sejak pendahuluan dibahas secara lebih mendalam pada bagian II dan III. Pada bagian II tentang "sejarah alam", Foucault menyatakan bahwa akar dari kemampuan klasifikasi manusia adalah pengamatan dengan mata, sedemikian hingga "inilah kemungkinan melihat apa yang bisa dikatakan oleh seseorang" (hal. 148). Lebih lanjut, pada bagian III tentang "struktur" ditekankan lagi bahwa "sejarah alam tidak lain hanyalah nominasi atas hal-hal yang tampak" (hal. 150). Hal ini sebenarnya wajar karena sejarah alam dapat ditarik dari perbedaan dasar dari perdebatan Plato dan Aristoteles. Aristoteles menjadikan empirisme sebagai dasar berpikir dan membuktikannya lewat kegiatan klasifikasi. Klasifikasi ini, tidak dapat dihindarkan lagi, menggunakan mata. Bahkan hingga abad renaisans, perluasan pemikiran manusia tentang alam semesta dibuka dan divalidasi oleh ekstensi mata manusia, yaitu teleskop. Hingga sekarang pun, hasil-hasil pengamatan antariksa digunakan untuk memvalidasi teori-teori tentang asal usul dan evolusi alam semesta oleh dunia astronomi.

Dalam Bab tentang Pertukaran, Foucault kembali menegaskan bahwa realitas empiris diamati oleh mata. Tetapi masalah praktis yang menjadi sorotan penulis di sini adalah kegagalan dari penerjemah buku Foucault. Dalam teks Bahasa Indonesia, pada halaman 236 disebutkan kalau "Urutan empirisitas dihubungkan dengan ontologi yang mengkarakterisasikan pemikiran klasik; tentu saja, dari permulaan yang sangat awal, pemikiran ini ada dalam satu representasi yang dipancarkan oleh fakta bahwa ia membebaskan kontinuitas wujud." Kalimat ini semestinya merupakan terjemahan dari "The ordering of empiricity is thus linked to the ontology that characterizes classical thought; indeed, from the very outset, this thought exists within an ontologyrendered transparent by the factthat being is offered to representation withoutinterruption; and within a representation illuminated by the fact that it releases thecontinuity of being" (Foucault, 1970:206). Terlihat bahwa para penerjemah maupun penyunting buku tidak teliti sehingga ada satu frasa yang hilang, yaitu "that being is offered to representation withoutinterruption; and within a representation illuminated". Kegagalan ini wajar karena dalam kalimat tersebut terdapat dua frasa "by the fact", yang membuat penerjemah melewatkan kalimat di antaranya. Sungguh demikian, frasa yang hilang tersebut, yaitu "oleh fakta bahwa wujud ditawarkan pada representasi tanpa interupsi" merupakan frasa penting karena menegaskan bahwa mata mengindera realitas secara langsung, baru kemudian membebaskan kontinuitas wujud. Hal inilah yang merupakan cara 
pandang manusia pada dunia sebelum abad ke-18.

\section{Kekuasaan Imajinasi atas Alam: Struktur Organik Bahasa}

Setelah menjabarkan mode wujud masa lalu yang bersifat empiris langsung, Foucault mengangkat wacana bahwa sejak abad ke-18, mulai terjadi pergeseran. Foucault menisbahkan perubahan cara pikir ini pada suatu struktur organik, yang muncul dalam empat jalan (hal. 258), yaitu hirarki karakter, karakter berhubungan dengan fungsi, "menghubungkan hal yang tampak jelas dengan hal yang tidak jelas, pada sebabnya yang lebih dalam, dan kemudian memunculkan sekali lagi dari arsitektur tersembunyi itu kepada tandatanda yang lebih jelas yang ditampilkan pada permukaan badan" (hal. 261), dan akhirnya mengaburkan "paralelisme antara klasifikasi dan nomenklatur" (hal. 262).

Adanya gejala ini mencerminkan memang manusia telah mencapai batasbatas inovatif dalam menghasilkan katakata dan akhirnya memilih menggunakan struktur organik. Pilihan ini sebenarnya langkah radikal yang lebih inovatif lagi. Dengan cara ini, manusia tidak lagi dibatasi oleh "batas-batas representasi" seperti judul bab ini. Dengan struktur organik, manusia membuat suatu "perluasan naungan" (hal. 241) yang "merupakan laut yang benarbenar tidak ada dasarnya" (hal. 241). Artinya, struktur organik membebaskan manusia dari kegiatan menciptakan katakata baru dan memilih untuk menggunakan pengetahuan kata-kata yang ia miliki untuk mengkombinasikan kata-kata atau memakai kata dari kamusnya untuk hal yang berbeda. Hal ini sungguh seperti laut yang tidak ada dasarnya karena potensi kata dan frasa yang terbentuk tak terbatas.

Dengan struktur organik, manusia mengklasifikasikan sesuatu bukan apa adanya, tetapi dengan membangun kemiripan-kemiripan dalam struktur pengetahuan, dan pada akhirnya, memberikan nama pada sesuatu dengan istilah yang tidak benar-benar senyatanya. Sebagai contoh, untuk masa modern ini, adalah "dentuman besar" atau "lubang hitam" yang merupakan dua istilah dalam bidang astronomi. Dua istilah ini jelas tidak sama dengan makna harfiahnya. Para ahli astronomi habis-habisan menyatakan bahwa yang dimaksud "dentuman besar (big bang)" bukan benar-benar "dentuman" atau "lubang hitam" bukan benar-benar "lubang yang hitam". Tetapi mengapa pula mereka memunculkan istilah itu dari awalnya? Ini karena adanya struktur organik, yang membuat mereka merelasikan sesuatu yang "apa adanya" di alam, dengan pengetahuan berbahasanya, lalu menggunakannya untuk menyebutkan objek tersebut, ketimbang menggunakan istilah-istilah baru. Kebiasaan ini, menurut penulis, akan berelasi dengan eksistensialisme manusia yang juga muncul pada era yang sama. Dengan memakai istilah yang tertanam pada struktur organik, ketimbang istilah yang benar-benar baru, manusia telah memberikan suatu objek suatu karakteristik manusiawi. Alien dari dunia lain yang mempelajari bahasa manusia akan mudah memahami bahasanya tanpa merujuk pada manusia sebagai subjek pembuatnya, karena setiap objek memiliki relasi langsung dengan kata-katanya sendiri. Tetapi dengan adanya struktur organik, alien akan kesulitan merelasikan hal ini. Mereka mungkin merelasikan "dentuman besar" dengan makna harfiah, seperti halnya orang awam.

Sebenarnya masalah ini dapat diangkat lebih dalam oleh Foucault dengan menyorot pada kebiasaan untuk menyingkat pada peradaban modern. Orang 
jaman sekarang, senang membuat singkatan-singkatan yang mudah dibaca (akronim). Di Amerika Serikat, bendabenda baru atau buatan baru diberikan nama akronim lebih pada kemudahan membaca seperti NASA atau LUCA (Last Universal Common Ancestor). Pada TNI, terdapat kebiasaan pula untuk menyingkat berbagai kegiatan atau lembaga sedemikian sehingga hanya dapat dipahami oleh orangorang yang benar-benar akrab dengan militer Indonesia, seperti Denbekang, Denjaka, Yonif, dan sebagainya.

Struktur organik karenanya menjadikan identitas bagi manusia dan kelompok manusia. Seperti halnya Dentuman Besar adalah istilah yang eksistensialis bagi ahli astronomi, begitu pula NASA bagi Amerika Serikat, dan Denbekang bagi TNI AD. Dengan melihat pada bagaimana seseorang menjadi terbedakan apakah ia ahli atau tidak dalam suatu bidang, dengan hanya melihat pada istilah-istilah teknis yang ia gunakan. Akibat struktur organik dan eksistensialisme, sering terjadi kesalahpahaman. Salah satu contoh yang lucu adalah bagaimana orang asing menyebut "Bahasa Indonesia" dengan istilah "Bahasa" dan memaknai bahwa "Bahasa" adalah "Bahasa Indonesia" ketimbang "bahasa (language)" secara harfiah.Dengan logika yang sama, tentu saja kita harus menyebut "Bahasa Inggris" dengan nama "language" ketimbang "english".

\section{Aku Berpikir, Maka Aku Ada}

Bab sembilan mengenalkan kembali konsep 'cogito'. Disini Foucault menjelaskan cara kedua yang digunakan manusia untuk mengubah dunia pada abad ke-18, yaitu mengartikulasikan cogito (hal. 356). Disinilah kaitan antara struktur organik dan eksistensialisme diangkat, seperti yang dicurigai penulis saat membaca buku ini mulai dari bagian belakang. Foucault membuat metafora bahwa orang-orang dalam masa klasik (maksudnya sebelum abad ke-18) "menjalin dari representasi dalam bentuk gambar atau tabel" tetapi "dia tidak pernah ditemukan di dalam tabel itu sendiri" (hal. 352). Artinya, manusia mengambil jarak dari apa yang dipelajarinya. Ketika abad ke-18, hal ini berubah dan manusia dapat dikatakan "ada di dalam tabel itu sendiri". Konsep cogito diangkat dari pernyataan Descartes tentang eksistensialisme "cogito ergo sum" yang berarti "aku berpikir, maka aku ada". Dengan menyadari bahwa manusia itu "ada", maka ia kemudian mampu mengangkat "ada" dirinya itu ke dalam apa yang ia pelajari, seperti yang diantarkan oleh para filsuf eksistensialis yang lahir di abad ini dan sesudahnya. Walau terdengar sangat biasa, tetapi ini adalah sesuatu yang baru. Foucault mengatakan "bagi pemikir klasik, manusia tidak menduduki satu tempat di alam ini melalui perantara 'alam' regional, terbatas dan spesifik yang dihadiahkan kepadanya, seperti kepada wujud yang lain, sebagai hak yang dibawa sejak lahir" (hal. 354).

Akibat kesadaran ini, manusia menjadi mengganda, atau dalam istilah Foucault (kembar). Satu sisi menjadi subjek yang mengetahui, sementara di sisi lain, sebagai objek pengetahuan (hal. 357). Jika kita adalah seorang ahli astronomi, maka kembaran kita adalah diri kita yang sebagai objek pengetahuan, sementara jika kita ahli psikologi atau orang biasa yang merenungi eksistensinya, maka kembarannya adalah subjek yang mengetahui. Atau mungkin sebaliknya. Tetapi intinya adalah bahwa manusia menjadi dua wujud dan karena ia harus mengambil satu wujud dalam satu waktu, ia berada dalam situasi ambigu. 
Dalam situasi ini, manusia mencapai keterbatasan dan keterbatasan ini "dirasakan dalam satu cross-reference dengan dirinya sendiri yang tidak berkesudahan" (hal. 363).

\section{Kematian Konsep Manusia}

Dalam bab terakhir tentang IlmuIlmu Kemanusiaan, Foucault menutup buku dengan menyatakan bahwa "manusia adalah ciptaan baru" (hal. 444-445) dalam kebudayaan Eropa dan "sekarang ini mungkin semakin mendekat" (hal. 445). Dalam paragraf selanjutnya dijelaskan bahwa "Jika susunan-susunan itu menghilang sebagaimana ketika mereka muncul, ...., pada akhir abad ke-18, maka orang bisa dengan yakin bertaruh bahwa manusia akan dihapuskan, seperti seraut wajah yang digambar pada pasir di tepi pantai" (hal. 445).

Frasa penutup yang menarik ini mencerminkan kalau Foucault mengkhayalkan kalau suatu saat, eksistensialisme manusia akan berakhir. Menarik kalau Foucault menarik garis waktu dari abad ke-18 ketimbang masamasa sebelumnya. Sebelum masa ini, humanisme telah hadir, tetapi diandang sebagai suatu kelompok, ketimbang individual. Eksistensialisme yang muncul di abad ke-18 lah yang menyatakan manusia sebagai suatu individual dengan hak-haknya. Tetapi apakah pemikiran ini suatu saat akan berakhir? Atau apakah manusia secara realitas akan berakhir? Banyak ancaman yang memungkinkan kemungkinan ini diterima. Secara fisik, perang dunia ketiga atau suatu bencana virus mematikan akan dapat memusnahkan manusia secara totalitas. Tetapi secara pemikiran, mungkin hal ini harus menunggu. Kita memang ada melihat kecenderungan kalau ilmu pengetahuan semakin objektif dalam memperlakukan manusia sebagai "hewan seperti hewan lainnya" dalam ilmu alam dan memperlakukan manusia sebagai "mahluk berperilaku terprediksi" dalam ilmu-ilmu perilaku konsumen, psikologi, dan bahkan komputasi. Tetapi ini dapat dipandang pula sebagai upaya manusia untuk lebih mengenal dirinya. Apakah ini regresi pada kemunduran eksistensialisme dengan menuju ke humanisme, lalu akhirnya meniadakan manusia, atau sebaliknya, membuat pengetahuan semakin menyadarkan kalau manusia adalah mahluk multidimensional yang tak akan dapat dipelajari oleh manusia di dalam dirinya sendiri, akan selalu menjadi suatu pertanyaan terbuka.

Lupanya Foucault pada "Bahasa Lain"

Secara keseluruhan, buku ini memang menggambarkan apa yang ia maksudkan: arkeologi ilmu-ilmu kemanusiaan. Disini Foucault menjadi semacam arkeolog yang menggali prasejarah ilmu-ilmu kemanusiaan masa kini. Menurutnya, ilmu-ilmu kemanusiaan hadir setelah suatu era klasik, dimana manusia memiliki bentuk pengetahuan yang terpisah dari dirinya sendiri. Setelah abad ke-18, tercapai batas-batas representasi yang memaksa manusia membentuk bahasa berdasarkan pengetahuan yang telah ada, yang disebutnya sistem organik, dan berdasarkan semacam kesadaran tentang eksistensi manusia di alam, lewat para filsuf eksistensialis. Dari dua sumber inilah ilmuilmu kemanusiaan berkembang dan menjadi bagian sehari-hari dalam kehidupan manusia modern saat ini.

Kritik yang dapat langsung muncul terhadap Foucault adalah bahwa ia hampir tidak memberikan satupun contoh atas pernyataannya. Hal ini membuat dirinya 
terjebak dalam paradoks, bahwa ia ingin menunjukkan sesuatu (karenanya ia menulis buku), tetapi ia sendiri abstrak dalam penjelasannya. Gaya Foucault hampir sama dengan Heidegger yang akhirnya sulit dipahami. Jika ia ingin benarbenar mendidik, tentunya ia membuat mudah agar apa yang ia paparkan sistematis, sehingga dapat dipelajari dengan cepat.

Dia menjelaskan kalau manusia di masa kini menggunakan struktur organik, dan ia sendiri menggunakan struktur organik. Hal ini terbukti pada pendahuluan yang memunculkan istilah heterotopia, yang merupakan gabungan kata "hetero" dan "utopia". Artinya, Foucault pun memakai kata lama, ketimbang menciptakan kata-kata baru. Kelemahan dari hal ini adalah ia akan cenderung eksistensialis. Dan memang Foucault seorang eksistensialis. Gaya menulisnya memberikan ciri khas dirinya sehingga dirinya mudah dikenal. Dan bagian pengantar dari Hayden White menegaskan hal ini : "karya-karya Michel Foucault ... adalah karya yang luar biasa sulit untuk disimak dalam persoalan-persoalan tertentu" (hal. v). Hal ini karena "pemikiran yang ia sodorkan disajikan dalam sebuah retorika yang didesain untuk menghalangi ringkasan, penguraian, pemuatan singkat untuk tujuan ilustratif, atau tafsiran dalam terminologi kritik tradisional" (hal. v). Dan bagi penulis, ini adalah karena hasrat eksistensial dari Foucault sendiri.

Faucault menjelaskan bahwa manusia sekarang memasuki dunia baru pemikiran yang membangun pengetahuan lewat struktur organik dan eksistensialismenya. Walau tidak menegaskan bahwa ini suatu kemajuan atau kemunduran, netralitas ini seolah mencerminkan kalau manusia mengalami kemunduran dengan mengadopsi pola pikir yang menyatu dengan alam. Tetapi bukan berarti bahwa manusia menggunakan struktur organik karena ia terbatas dalam daya kreasi dan representasinya, tetapi justru karena pengetahuan manusia sudah lengkap. Dengan menyatakan sesuatu dengan kata-kata baru, manusia sedang mencari pengetahuan. Karenanya ketika dimunculkan kata baru, orang langsung bertanya, "apa itu?". Tetapi di masa sekarang, pengetahuan manusia telah cukup lengkap sehingga memungkinkan menisbahkan sesuatu objek baru dengan kata-kata lama. Dengan melihat sesuatu asal usul alam semesta dalam suatu "ledakan besar" misalnya, orang langsung tahu bahwa ia semacam "ledakan yang besar". "Ledakan" dan "Besar" tidak dikombinasikan secara manasuka tetapi karena adanya kemiripan dengan struktur pengetahuan yang telah ada pada manusia, atau dalam istilah Foucault, dalam struktur organik.

Lagi pula, apakah benar-benar orang sebelum abad ke-18 memang menabur jarak dengan alam? Hal ini memerlukan konfirmasi lebih jauh. Bisa jadi ia adalah suatu tema yang dipaksakan oleh Faucault sendiri untuk membenarkan gagasannya bahwa manusia modern telah mencapai batas-batas representasional dan mulai melihat ke dalam dirinya sendiri. Jika melihat dalam bidang spiritualisme, masalah ini telah lama dicapai. Manusia telah masuk ke dalam dirinya sendiri dalam bentuk sufisme dan paradigma seperti wahdatul wujud dalam mistisme tasawuf.

Foucault hanya memahami dari segi yang begitu sehari-hari dari kemampuan berbahasa manusia. Jika Foucault menyorot pada dunia sastra, ia tentunya menemukan permainan bahasa yang sangat banyak sejak jaman dahulu. Sebenarnya ia telah 
membahas masalah puisi ini. Ia menyebutkan bahwa "penyair membawa kemiripan kepada tanda-tanda yagn membicarakannya" (hal. 55) dan bahwa "penyair memenuhi fungsi yang bertentangan: perannya bersifat alegoris; dibawah bahasa tanda dan di bawah kesalingpengaruhan distingsi mereka yang secara tepat digambarkan, dia menekan telinganya untuk mendengar 'bahasa lain', bahasa, tanpa kata atau wacana, kemiripan, (hal. 55). Ini sebenarnya suatu petunjuk penting bagi Faucault, tetapi ia sepertinya tidak mengindahkan hal ini dan terus masuk dalam dunia di luar seni tanpa menjelaskan apakah seni merupakan suatu penyimpangan atau tidak dalam sistem klasifikasi sejarahnya. Apakah seni itu suatu heterotopia? Jika ya, bukankah ia merusak dari sejak awal orang memiliki daya imajinasi jauh sebelum abad ke-18. Jika tidak, mengapa ia tidak dibahas mendalam oleh Foucault?

\section{Perbaikan Fundamental}

Berhubung Foucault sendiri telah meninggal dunia, maka perbaikan fundamental akan lebih terarah pada layout yang dibuat oleh penerjemah untuk edisi Indonesia. Dapat dipahami bahwa penerjemah dan penerbit berusaha mempertahankan bentuk asli dari buku Order of Things. Tetapi karena buku ini merupakan buku yang harus dapat dibaca secara menyeluruh, maka perlu ada perbaikan pada tata isi dari buku. Tanpa mengurangi atau menambahkan isi seperti gambar atau diagram, maka upaya memudahkan pembacaan adalah dengan menata ulang tulisan. Tulisan dalam buku ini dibuat dengan spasi yang sangat rapat. Perlu diperhatikan bahwa Foucault membuat buku ini dengan alinea-alinea panjang. Sering ditemukan kalau dalam satu halaman tidak mengandung satu paragraf sama sekali, padahal satu halaman dapat mengandung 36 baris (misalnya halaman 278). Untuk itu, tulisan harus dibuat dengan spasi yang lebih renggang dan huruf yang lebih besar. Tentu saja, hal ini akan meningkatkan jumlah halaman secara signifikan. Bisa saja dalam upaya ini, jumlah halaman meningkat dua kali lipat menjadi 800 halaman. Hal ini dapat diatasi dengan memakai hard cover, ketimbang soft cover seperti yang sekarang digunakan. Harga dapat lebih mahal tetapi buku dapat lebih awet dan lebih memiliki nilai estetik jika dipajang di suatu lemari.

Sementara itu, untuk mengurangi kesulitan dalam membaca, referensi dapat menggunakan catatan kaki, ketimbang catatan akhir. Hal ini menghindari pembaca harus bolak-balik kertas pada buku yang memang sudah tebal. Pembaca dapat dengan mudah kehilangan halaman jika terlalu sering membolak-balik halaman.

Bagi penulis di masa datang dengan genre eksistensialisme seperti Foucault, ada baiknya jika menambahkan lebih banyak gambar atau diagram untuk membuat penjelasan. Hal ini mungkin sulit bagi suatu pembahasan yang bersifat sangat general dan abstrak seperti karya-karya filsafat. Tetapi sebaiknya hal ini diupayakan. Gambar atau diagram dapat menjadi semacam titik henti sementara atau "oasis" bagi pembaca setelah membaca berlembarlembar halaman tanpa henti dalam aliran wacana yang kompleks dan melelahkan mata.

\section{Simpulan dan Rekomendasi}

Buku ini memberikan sebuah analisis terhadap sejarah hubungan manusia dengan alam dalam analisis pada aspek kebahasaaan. Gambaran distopia tentang bagaimana suatu saat konsep manusia akan punah menggelitik untuk dicermati dari 
perspektif perkembangan teknologi saat ini, khususnya teknologi kecerdasan buatan. Dalam kritik atas struktur organik bahasa yang ia telisik, Foucault sendiri tak mampu menghindari untuk membuat istilah berbasis struktur organik seperti heterotopia.

$$
\text { Arkeologi pengetahuan }
$$

kemanusiaan (humaniora) yang ditawarkan buku ini memang memberikan sesuatu yang baru dalam kesadaran banyak orang, yaitu bahwa konsep manusia itu adalah sebuah penemuan dan penemuan ini akan usang suatu saat, berganti dengan konsep lain yang muncul dari tak terhingga kombinasi kata dan pemahamanpemahaman baru tentang manusia itu sendiri.

Sungguh demikian, mudah bagi pembaca untuk bertanya: mengapa Faucault hanya mengambil sampel pada peradaban Eropa dan Barat secara umum? Apakah mungkin untuk melihat dari sudut pandang antropologi sehingga memunculkan antropologi ilmu-ilmu kemanusiaan? Apakah arkeologi ilmu kemanusiaan barat sejalan dengan katakanlah, arkeologi ilmu kemanusiaan Nusantara yang berbudaya oral?

Buku ini akan berguna bagi para peneliti filsafat bahasa dan filsafat barat maupun eksistensialisme modern karena menusuk pada bagian paling kontemporer dari petualangan kognitif manusia: bahasa. Apa lagi setelah bahasa yang dapat dijamah oleh filsafat? Ini adalah sebuah pertanyaan filosofis yang dapat menghasilkan banyak pemikiran. Tetapi sungguh, bagi pembaca ilmu komunikasi, buku ini menjadi sebuah tantangan dalam memahami gaya komunikasi seorang filsuf yang mempelajari bahasa. Ibaratnya, seperti seorang yang membicarakan tentang kreativitas tetapi menyampaikannya dengan tidak kreatif, begitu pula, Faucault membicarakan bahasa tetapi menyampaikannya dengan bahasa yang sulit dipahami. Sungguh demikian, para pembaca yang lebih 'keras' mungkin akan menganggap Faucault masih berupa bacaan ringan dibandingkan karya-karya Martin Heidegger.

Dalam alam pikiran ilmu-ilmu teknis, terdapat dilema antara penyampaian sesuatu yang eksak dengan penyampaian sesuatu dengan mudah. Dilema antara kesederhanaan dan ketepatan kata menjadi sebuah hal yang dihadapi oleh para pengarang yang berusaha menjabarkan pikiran-pikiran kompleksnya pada buku bagi para pembaca umum. Dan dalam hal ini, direkomendasikan bagi pengarang buku sejenis untuk lebih memberatkan sisi kesederhanaan dan kemudahan bacaan dan membiarkan sisi teknis dan eksak pada tulisan-tulisan di jurnal ilmiah.(RU) 